pecypc]. Доступно: https://journal.iitta.gov.ua/index.php/itlt/article/view/ $25 / 13$

4. Міжнародна конвенція про підготовку і дипломування моряків та несення вахти 1978 року. [Електронний ресурс]. Доступно: http://zakon0.rada.gov.ua/laws/show/995_053.

5. Осадчий В.В., Осадча К.П. Сучасні реалії і тенденції розвитку інформаційно-комунікаційних технологій в освіті, Інформаційні технології і засоби навчання, т. 48, № 4, С. 47-57, 2015.

DOI https://doi.org/10.30525/978-9934-26-146-6-34

\title{
МОДЕЛІ ФАХОВО ОРІЄНТОВАНОГО НАВЧАННЯ ХІМІЧНИХ ДИСЦИПЛІН
}

\author{
Філіппова Л. В. \\ кандидат хімічний наук, доктор педагогічних наук, дочент, \\ доиент кафедри медичної та загальної хімії \\ Національний медичний університет імені О. О. Богомольия \\ м. Київ, Украӥна
}

Сьогоднішній запит щодо якості навчання хімічних дисциплін та методика навчання хімічних дисциплін як вагома складова фармацевтичної освіти потребує постійного творчого пошуку, оновлення змісту, форм та методів навчання, динамічних змін у підходах до впровадження інноваційних технологій навчання та їх ефективного поєднання з традиційними навчальними технологіями. Сучасний запит до якості навчання хімічних дисциплін $\mathrm{M}(\Phi) 3 В О$ значною мірою обумовлюється актуальними i перспективними потребами фармацевтичної галузі, прогнозованими вимогами до професійної компетентності і конкурентоспроможності фахівців на ринку праці, а його реалізація - ефективною взаємодією у тріаді «освіта-наука-виробництво».

При створенні моделі фахово орієнтованого навчання базових хімічних дисциплін нами розроблена методика проведення усіх форм навчальних занять та сконструйована структура навчально-методичного комплексу. Однією з визначальних детермінант змісту освіти є ії мета, яка $є$ соціально та історично обумовленою, оскільки визначається суспільними запитами. Це означає, що зміст освіти формується відповідно до вимог життя, виробництва, рівня розвитку наукового знання. В Законі Україні «Про вищу освіту» (2014) [1] чітко 126 
зазначається, що метою професійної освіти є підготовка фахівців для «високотехнологічного та інноваційного розвитку країни, самореалізації особистості, забезпечення потреб суспільства, ринку праці та держави у кваліфікованих фахівцях». Таким чином, при конструюванні змісту фармацевтичної освіти мають бути враховані трансформації освітнього процесу, зміни в технології виробництва та застосування лікарських препаратів, розширення сфер діяльності фармацевтів в сучасних умовах, історично обумовленні чинники, які потребують належного теоретикометодологічного обгрунтування.

Проаналізував ролі усіх хімічний дисциплін, які вивчають сучасні магістри, побачили, що у формуванні професійної компетентності майбутніх фахівців фармацевтичного сектора галузі охорони здоров'я України, хімічні дисципліни охоплюють широке предметне поле, необхідне для виконання професійної діяльності, зокрема:

- реалізація фармацевтичної опіки;

- надання консультаційних послуг щодо ЛЗ;

- виготовлення лікарських форм промислового та аптечного виробництва;

- проведення товарознавчої експертизи лікарських засобів,

- визначення термінів та забезпечення умов їх зберігання та утилізації.

Для того щоб підготувати висококваліфікованих конкурентоспроможних спеціалістів - магістрів фармації, необхідно забезпечити високу якість фахової та фундаментальної підготовки у процесі навчання хімічних дисциплін, яким належить визначальна роль у системі підготовки майбутніх фармацевтів.

Науковці стверджують, що визначальну роль займає зміст навчання. Здобувачі вищої освіти мають розуміти реальний стан речей та взаємозв'язки між різними галузями знань [2], формування фахівця потребує узгодженості навчального матеріалу та взаємодії знань, здобутих в різних навчальних дисциплінах. Саме хімічні дисципліни закладають фундамент, на якому будуються фахові знання та уміння, що доповнюються та формуються впродовж усього професійного життя, тому такими важливими $\epsilon$ принципи конструювання змісту цих дисциплін, критерії добору навчального матеріалу, його структурування, ущільнення та оновлення. Очевидно, що реалізація професійно орієнтованого навчання, перетворення особистості студента в спеціаліста-професіонала не може бути ефективним без якісної теоретичної бази знань з фундаментальних наук. Лише за такого підходу створюються умови для розвитку особистісного потенціалу, системне та усвідомлене опанування фаховими навчальними дисциплінами. 
Попри пріоритетність задекларованої нами професійно орієнтованої складової у формуванні змісту базових хімічних дисциплін має бути врахована важливість формування цілісної наукової картини світу в рамках актуальних природничо-наукових парадигм, усвідомлене поєднання гуманітарних i природничо-наукових знань, що сприяє підвищенню професійної культури майбутніх фахівців, їх умінню компетентно розв'язувати професійні завдання. Це уможливлює у процесі вивчення хімічних дисциплін формувати професійне мислення майбутніх магістрів на основі інтегрованого типу пізнання хімічних явищ, процесів та закономірностей тощо.

Для вирішення поставленого завдання необхідно здійснити професійно-прикладний підхід при якісно оновленому змістовому наповненні навчальних програм базових хімічних дисциплін, а також надати більшого професійного спрямування теоретичному матеріалу та змісту практичних занять. Аналіз змісту хімічних дисциплін в рамках нашого дослідження підпорядковувався орієнтуванню на майбутній фах, логіці формування основних змістових ліній та часовій послідовності їх вивчення. Як було доведено [3] при розробленні методики навчання хімічних дисциплін доцільною $є$ опора на проблемний тип інтеграції у структуруванні знань на основі базових для майбутньої професії змістових ліній та дотримання принципів реалізації компетентнісного та інтегративного підходу.

Таким чином, при структуруванні змісту дисципліни ми використовували комплекс методологічних підходів, а саме:

- інтегративний підхід, який розглядає цілісність всієї системи, складних об'єктів;

- модульний підхід супроводжується оформленням навчального матеріалу у вигляді блоків, які мають завершеність змісту;

- компетентнісний підхід, який орієнтований на формування фахової компетентності;

- системний підхід, грунтується на інтеграції, систематизації, на відокремлені понять з різних дисциплін.

Спираючись на такий комплексний підхід ми намагалися реалізувати інтеграцію цілей, змісту, форм та методів навчання, знань та вмінь 3 орієнтуванням на майбутню професійну діяльність, об'єднуючи найважливіші та найскладніші структурні елементи міждисциплінарними зв'язкам. Це об'єднання спочатку виражається у вигляді засвоєння основних законів хімії, термінів, понять, а потім відбувається перетворення на систему загальних теорій. За допомогою такого підходу відбувається формування цілісної системи професійно значущих знань. 
Окрім цього, всебічний розвиток когнітивних здібностей, який $€$ передумовою творчого розвитку фахівця впродовж життя.

\section{Література:}

1. Про вищу освіту: Закон України. Відомості Верховної Ради (ВВР), 2014, № 37-38, ст. 20004. URL: https://zakon.rada.gov.ua/laws/show/1556-18

2. Стучинська Н.В., Філіппова Л.В. Природничі дисципліни в контексті особливостей розвитку національної фармацевтичної освіти на сучасному етапі. Педагогічна освіта: теорія і практика: зб. наук. праџь Кам'янець-Подільського національного університету імені Івана Огієнка, Інститут педагогіки НАПН України, 2020. Вип. 26. С. 250-155.

3. Філіппова Л.В. Модель професійно орієнтованого навчання хімічних дисциплін магістрами фармацевтичних закладів. Науковий часопис Національного педагогічного університету імені М. П. Драгоманова. Серія 5. Педагогічні науки: реалії та перспективи. 2021. Вип. 79. С. 180-187. 